\section{FedUni ResearchOnline \\ https://researchonline.federation.edu.au}

Copyright Notice

This is the published version of:

Panagodage Perera, N. K. (2019). Too many rib ticklers? Injuries in Australian women's cricket (PhD Academy Award). British Journal of Sports Medicine, 53(22), bjsports-2018-099629-2018-099629v1. https://doi.org/10.1136/bjsports-2018-099629

Copyright $\odot 2019$ The Author(s). All rights reserved. Published by BMJ. This is an Open Access article distributed under the terms of the Creative Commons Attribution-Non Commercial 4.0 International License (http://creativecommons.org/licenses/by-nc/4.0/), which permits others to distribute, remix, adapt, build upon this work non-commercially, and license their derivative works on different terms, provided the original work is cited and the use is non-commercial. Commercial use is not permitted. 


\title{
Too many rib ticklers? Injuries in Australian women's cricket (PhD Academy Award)
}

\author{
Nirmala Kanthi Panagodage Perera (1) 1,2
}

'Department of Medicaland Health Science, University of Linköping, Linköping, Sweden ${ }^{2} S c h o o l$ of Health and Life Sciences, Federation University Australia, Ballarat, Victoria, Australia

Correspondence to

Dr Nirmala Kanthi Panagodage Perera, Department of Medical and Health Science University of Linköping Linköping Sweden; perera.nk@outlook.com

Accepted 8 November 2018 Published Online First 17 November 2018

Check for updates

(C) Author(s) (or their employer(s)) 2019. No commercial re-use. See rights and permissions. Published by BMJ.

To cite: Panagodage Perera NK. Br J Sports Med 2019:53:1436-1437.

\section{WHAT DID I DO?}

I provided the first detailed epidemiological profile of incidence, nature and mechanism of injuries sustained by Australian female cricketers, through compilation and analysis of multiple data sources.

\section{WHY DID I DO IT?}

I grew up playing 'mixed' cricket and now it is a popular sport among women around the world. While sports participation carries many health benefits, one negative consequence is an increased risk of injury in participants. Evidence-based injury prevention programmes can reduce this risk when the causes of injury are known. ${ }^{1}$ However, before my $\mathrm{PhD}$, little was known about the injuries in women's cricket.

\section{HOW DID I DO IT?}

First, I conducted a systematic review of the literature describing injuries across competitive team bat-or-stick sports played by women. ${ }^{2}$

I then generated a population-based epidemiological profile of cricket injuries sustained by women from multiple existing data sets. This included: (1) Existing data sources relating to hospital presentations in Victoria and Queensland. ${ }^{3}$ (2) Successful insurance claims from the cricket-specific national insurer in Australia.

I also examined the nature and incidence of cricket injuries in elite female players using Cricket Australia's Athlete Management System (AMS) to provide an overview of injuries sustained at the elite level. $^{4}$

Finally, I surveyed female cricketers across Australia to describe their self-reported worst injury during the 2014-2015 season and their treatment sources. ${ }^{5}$

\section{WHAT DID I FIND?}

$\mathrm{My} \mathrm{PhD}$ is one of the largest compilations of injury cases in women's cricket. The systematic review findings indicate that injury incidence proportions were higher than expected based on previous studies on team bat-or-stick sports. ${ }^{2}$ Hospital presentation and insurance claims data showed injuries to the wrist/ hand, knee/foot and head were common in community-level players. AMS data demonstrated thigh, wrist/hand and knee injuries were common in elite players and running and gradual onset were the most common injury mechanisms. Also, at the elite level wrist/hand and lumbar spine injuries were the most common time loss injuries. Dislocations/sprains/ strains, fractures, and muscle and joint injuries as well as gradual-onset injuries were the most common injury types regardless of the level of play. All-rounders and pacebowlers had the greatest risk of injury than other dominant player skills across all levels of play.
The survey findings substantiate results from hospital presentation, insurance claims and AMS data in terms of nature and location of injuries and all-rounders and pacebowlers having high risk of injury discussed above. Also, the survey revealed that most injuries were of a low severity and more likely to be treated in primary care settings from allied health professionals. Majority of injures were self-treated by players or did not receive treatment.

\section{WHAT IS THE MOST IMPORTANT CLINICAL IMPACT/PRACTICAL APPLICATION}

Injury prevention in women's sports is a novel and emerging field of research interest. My PhD has contributed to inform targeted injury prevention interventions, so more female cricketers are able to enjoy the sport that they love for longer.

- Most common injuries at the community level were injuries to the head, wrist/hand, knee/ foot. Therefore, the injury prevention efforts at the community level should focus on use of helmets and skills training to prevent head injuries, skills training to prevent hand/wrist injuries, and neuromuscular training to prevent lower limb injuries.

- Most common injuries in women's cricket at the elite level were to the wrist/hand and the lumbar spine. Therefore, the injury prevention efforts at the elite level should focus on skills training to prevent wrist/hand injuries, correcting bowling technique, overall load management (eg, Cricket Australia's Bowling Workload Guidelines) and back stability programmes to reduce the risk of injures to the lumber spine.

- Gradual-onset injuries were common regardless of the level of play and workload management and increasing capacity (physical preparedness) is important to minimise risk of these injuries.

- Allied health professionals have a significant role in injury management. Implications for local primary healthcare services can be both financial and educational, with practitioner effectiveness requiring an appropriate knowledge base and to provide appropriate resources and educate the community to facilitate effective injury management.

Funding Nirmala Kanthi Panagodage Perera was supported a Federation University Australia Postgraduate Research Scholarship via it's scheme.

Competing interests None declared.

Patient consent Not required.

Ethics approval Federation University Australia Human Research Ethics Committee. 
Provenance and peer review Not commissioned; internally peer reviewed.

ORCID iD

Nirmala Kanthi Panagodage Perera http://orcid.org/0000-0001-6110-8945

\section{REFERENCES}

1 Finch C. A new framework for research leading to sports injury prevention. I Sci Med Sport 2006;9:3-9

2 Panagodage Perera NK, Joseph C, Kemp JL, et al. Epidemiology of injuries in women playing competitive team bat-or-stick sports: A systematic review and a meta-analysis. Sports Med 2018:48:617-40.
3 Perera N, Kemp J, Joseph C, et al. Hospital treated cricket injuries in community level female players: an analysis of hospital-presentation data from Victoria and Queensland, 2002-03 to 2013-14, inclusive. J Sci Med Sport 2017:20S:40.

4 Perera N, Kountouris A, Kemp J, et al. Injuries in elite australian female cricketers. $\mathrm{Br} J$ Sports Med 2017;51:373.1-373.

5 Perera N, Kountouris A, Kemp J, et al. Injuries in australian female cricketers and their treatment sources: An analysis of self-reported survey data from 2014-15 season. $\mathrm{Br} J$ Sports Med 2017;51:373.2-373.

6 Perera N. Injury epidemiology among Australian female cricketers. Federation University Australia 2016. 